\title{
A Sociology of TARoT
}

\author{
Mike Sosteric
}

Abstract. This article attempts to establish a sociology of the occult in general, and a sociology of the Western tarot in particular. The tarot is a deck of 78 cards invented in Italy in the fifteenth century. From humble beginnings as a device for gaming or gambling, the tarot became invested with occult, mystical, divine, spiritual, and even psychological significance. This investing became part of a larger strategy of discipline and indoctrination to ease the transition from preindustrial structures of power and authority to industrial and bureaucratic structures. That tarot, associated as it was with the emergence of elite Freemasonry, helped provide new ideologies of power and ways of existing within new tightly structured, bureaucratic organizations.

Keywords: Tarot, freemasonry, discipline and control, ideology, occult, religion, halo/sharp.

Résumé. Cet article vise à établir une sociologie des sciences occultes en général et une sociologie du tarot en particulier. Le tarot comprend 78 cartes et a été inventé en Italie au XVe siècle. De ses débuts modestes en tant que jeu, le tarot s'est vu associé aux sciences occultes, mystiques, divines et spirituelles, prenant même une signification psychologique. Cette dimension s'est inscrite dans une plus grande stratégie de discipline et d'endoctrinement dans le but de faciliter la transition des structures préindustrielles du pouvoir et de l'autorité à des structures industrielles et bureaucratiques. Ce tarot, associé à l'émergence de la francmaçonnerie d'élite, a contribué aux nouvelles idéologies du pouvoir et des moyens d'exister dans les confins d'organisations très structurées et bureaucratiques. Mots-clés: Tarot, franc-maçonnerie, discipline et contrôle, idéologie, occulte, religion. 


\section{INTRODUCTION}

1. cademics have long displayed an interest in psychical research, paraIpsychology, occult practices, and other phenomenon at the boundaries of science (Collins \& Pinch 1982; Truzzi 1974a, 1974b; Zaretsky \& Leone 1974; Robbins \& Anthony 1979). This multidisciplinary interest is traceable even to the founders of specific disciplines, although we might be surprised to find that thinkers like Freud (Devereux 1953), Sandor Ferenczi (Gyimesi 2012), William James (Sech, de Freitas Araujo \& Moreira-Almedia, 2013) and other disciplinary luminaries took seriously the investigation of 'boundary phenomenon.' Sociologists have also expressed some interest in boundary phenomenon, the occult, secret societies, and such, but it has been far from all consuming. Simmel (2006) attempted to establish a sociology of secret societies and Tiryakian (1972) attempts to move us 'toward a sociology of esoteric culture.' Some work has been done in the Sociology of Science (Collins \& Pinch 1982), and Hess (2007) has examined spiritism in some detail, but by and large sociologists have been silent, both empirically and theoretically, on issues of the occult.

This lack of sociological interest and almost dismissive orientation can perhaps be traced to the dominant assumption that secularization and scientific rationality would eventually kill such practices outright (Lundskow 2008). It could also be partly due to their disenchantment with natural forces (Stone 2006), partly to the Durkhemian view of religion as a basic expression of the underlying social order (Durkheim 1915), partly to an anti-occult narrative that dismisses such interest as 'heresy' or 'superstition' (Hanegraaff 2005; Versluis 2007), and partly to Marxian skepticism of religion and spirituality. As a result, sociology has paid little research attention to boundary subjects like, for example, the tarot. The tarot is a deck of cards used for occult and mystical practice with a history of socio-political intrigue dating back to the fifteenth century (Dummett 1980), but which hardly registers on the sociological radar at all. There is some interest in a scholarly study of tarot outside of sociology, but even there the 'paucity of material' requires a multidisciplinary approach (Farley 2009, 5) Farley $(2009,1)$ attributes the lack of interest in the tarot to its association with "shoddy soothsayers and confidence tricksters," and that is certainly part of it. Whatever the reason, the lack of sociological interest in the tarot represents a significant theoretical and empirical lacuna because, as this paper will attempt to demonstrate, there are reasons to believe that the tarot has far more sociological significance than first attributed to it. In this paper we see that the Western tarot became a weapon used in an esoteric (i.e., secret) class war by ruling elites 
to regain the power they lost as Church authority, and elite authority in general, were dismantled during the eighteenth and nineteenth centuries as a result of the English, French, and scientific revolutions.

\section{What Is TARot?}

The characteristics of a tarot deck are peculiar. A tarot deck is a set of cards in two parts (Dummett 1980) — a set of fifty-six minor cards, minor arcana, or suit cards, and a set of 22 additional 'major' cards. In the 'minor' part of the deck there are four suits (Swords, Batons, Cups, and Coins), each of which contains the cards ace through ten as well as a King, Queen, Knight, and Jack. The major cards contain a Fool card, traditionally labeled 0 , and twenty-one other major arcana or trump cards, numbered from I to XXI. Historically, the trump cards were:

\begin{tabular}{|c|c|c|c|c|c|}
\hline I & $\begin{array}{l}\text { The } \\
\text { Mountebank }\end{array}$ & VIII & Justice & $\mathrm{XV}$ & The Devil \\
\hline II & The Popess & IX & The Hermit & XVI & The Tower \\
\hline III & The Empress & $\mathrm{X}$ & $\begin{array}{l}\text { The Wheel } \\
\text { of Fortune }\end{array}$ & XVII & The Star \\
\hline IV & $\begin{array}{l}\text { The } \\
\text { Emperor }\end{array}$ & XI & Fortitude & XVIII & The Moon \\
\hline V & The Pope & XII & $\begin{array}{l}\text { The Hanged } \\
\text { Man }\end{array}$ & XIX & The Sun \\
\hline VI & Love & XIII & Death & $\mathrm{XX}$ & Judgement \\
\hline VII & The Chariot & XIV & Temperance & XXI & The World \\
\hline
\end{tabular}

According to Dummet $(1980,7)$, it is the presence of the twenty-two 'triumphs' that always "distinguishes the tarot pack from every other 
kind of playing-card pack." In a tarot deck, the minor arcana may or may not be painted with images; however, the major arcana are almost always illustrated with fanciful, mythological, spiritual, and cultural imagery.

\section{Divination}

When the Tarot first came into existence the deck was little more than a picture book, a system for gaming, possibly a device for gambling (Dummett 1980) and held no mystical, magical, or divinatory significance (Farley 2009). The tarot did, arguably, have allegorical significance and Farley (2009) provides a convincing argument that the tarot, originating within the cultural milieu of the Egyptian Mamlūk caste, was reinvented as an allegory for the life of the Viscontis, rulers of Milan, but beyond that there is no evidence (despite protestations of authors like Place (2005) who erroneously assert the tarot's mystical credentials based on its association with the mystical secular art of the Renaissance), to suggest it was anything other than a simple game of cards. According to Farley $(2009,3)$, "It began its life as a game with no purpose beyond providing mental stimulation. It contained no esoteric wisdom, could provide no spiritual advice and gave no clue as to how to conduct one's life." These days, however, the tarot has become much more. At its most sinister, the tarot is an indicator of, and perhaps gateway to, satanic worship (Rudin 1990).

Some traditional Christians, in particular those of an evangelical bent, have a powerful belief that the tarot is a book of the devil. This belief is so powerful that even to mention the word 'tarot' causes a visceral, fear-based reaction (Anon 2012). However, the tarot is not primarily seen in this way. Much more common is a belief that the tarot was designed for, and can be used as, a tool for cartomancy. In the early days of tarot mysticism it was thought that the tarot could provide a gateway or a channel that would facilitate communion with jinn, angels, and other exalted heavenly hosts. More recently, the superstition has been tempered, but the belief in gateways and channels remains, and in some surprising places. These days, the most respectable way to present the art of divination would be as an attempt to explain the world where science seems unable to work (Maitre \& Becker 1966), as a tool for developing the 'inner eye' (Noddings \& Shore 1984), or perhaps a way to tap into the knowledge contained in the unconscious (Bala 2008). The tarot also holds a respected place in Jungian psychology as a way to connect with "that level of nature that lies behind stars and cards and psyche and is expressed in all of them" (Spiegelman 1998, 93). For Spiegelman "that 
level of nature" is the level of 'archetypes.' According to Spiegelman 'archetypes' represent grand cosmic templates and patterns all of which can, when suitably connected with, yield prescient and prophetic content.

However, as noted above, while the twenty-two trump cards that distinguish a tarot deck from a 'normal' pack may have been developed with allegory in mind (Farley 2009; Pratesi 1989), there are no established references to the use of the tarot as a fortune-telling tool until the middle of the eighteenth century (Dummett 1980). The first association of the tarot with mystical or divinatory proclivities emerge specifically with the work of Antoine Court de Gébelin, M[onsieur] le C[omte] de M. and Etteilla (whose real name was Jean-Baptiste Alliette). Both can be traced to the publication, in 1781, of Court de Gébelin's nine-volume Le Monde primitif, more precisely, to two seminal essays, one by Court de Gébelin, and the other by M. le C. de M. (Dummett 1980). Prior to this publication, the tarot was seen as nothing more than a vehicle for a game of cards, and an outlet for the vice of gambling. Afterward, however, the tarot gradually became a divinatory masterpiece and key to all life's mysteries. Before we address the question of why the tarot changed, and what is significant about the dates, it will be worthwhile to highlight just what the tarot has become since Court de Gébelin first set the ball rolling

\section{A hermetic Mystery tool}

It is surprising enough that the tarot, a mere pack of cards with pretty pictures, would become a significant tool in the repository of the Jungian therapist, but even more surprising is the spiritual import that has been placed on this not-really-so-ancient pack of cards. For many, the tarot has become a hermetic or spiritual tool. 'Hermetic,' in this instance, is to be understood both as "a tool of occult science and magic," and as "having a lineage traceable to Hermes Trismegistus." Thrice-great Hermes was the mythological author of a corpus of works teaching Hermeticism, a belief that the world can be influenced through contact with and exploitation of 'heavenly forces' - magic in other words. In this view, the tarot is a book of 'special' symbols, a "perfectly simple philosophical machine" that contains "the whole science" and "that astonishes by the depth of its results" (Levi 2002, 85). According to this line of thought, the tarot is not an 'open' book; rather, it is a secret book, a hidden book, one open only to those who undergo a "special training of the mind" (Ouspensky 1976, 2). With the tarot, it becomes possible to mediate between humanity and the Godhead, between god/spirit/consciousness and 
profane human existence (Semetsky 2011a). In the Hermetic tradition, tarot is variously a teaching tool used to develop special skills, a "complete code of Hermetic symbolism" (Ouspensky 1976, 2), a "summary of Hermetic Sciences" (Ouspensky 1976, 6), and a way of revealing the "interface between human kind and the cosmos" (Jorgensen \& Jorgensen 1982, 381).

Occult reality, then, is "idealistic" or spirit like in fundamental character. The material world (that world available to sensory experience) is held to be an illusion; matter, in other words, is dominated by spirit. The tarot symbolically represents material phenomena (heavenly bodies, political, family, economic relations) in terms of nonmaterial principles and forces thought to constitute the True nature of the universe. Though hidden and concealed, these supernatural forces are accessible to human beings by way of intuitive, mystical, or psychic insights. (Jorgensson \& Jorgensen 1982, 380)

As Jayanti (2004, ix) notes, “... the images in the true tarot are liberating in their effect as they present the reality behind appearance which is the search of all aspirants... The tarot is the easiest gateway to the Great Mysteries of Life." In sum, in the magical mystery traditions of the Western world, the tarot is an esoteric tool of mysticism, a supreme instrument of divination, a deck of secret knowledge, an ancient Egyptian fountain of wisdom, a bible of bibles, a bible of humanity containing wisdom from the time the world was born, a book of Thoth, a book of Adam, a revelation of ancient civilizations, and the whole cosmic/cosmological/ theological and philosophical ball of wax rolled up into one convenient package of cheaply illustrated paper cards (see Dummett 1980; 2007).

1. Not the "fake" Tarot, but the "true" tarot. Ever since the Freemasons took over tarot imagery there have been attempts to "manifest" the "true" tarot. Commentators like Crowley and Waite, and all those before, approach the tarot as if it is a puzzle in need of solution, or a cosmic gestalt in need of expression. For all these people there is an underlying truth that needs revealing. Thus each approach is an attempt to uncover the true meanings of the cards. Truth can be located in mystical gnosis (as the Freemasons attempt to do) or archetypal revelation (as Jungian therapists to do), but either way there is an attempt to find the "true" tarot. Of course, the argument of this paper is essentially there is no "true" tarot. There may be spiritual and gnostic truths to discover in this world, but these truths are not inherent in the tarot. The tarot is a human construction and thus the question is not whether we can discover the "true" tarot, but are we satisfied with the thing that we have constructed. Personally I am not satisfied with the masonic Tarot and have been working to see something new, something more progressive, constructed in its place (see comments in the conclusion of this paper). 


\section{MAgICAL SEMIOTIC REVELATION/THERAPY}

We will return to analysis of 'hermetic mysteries' of tarot shortly. It is worth noting that out of the view that tarot is some magical, spiritual tool have arisen other schools of thought. Noteworthy is the Jungian school of psychology where you will find the same hyperbolic discourse on the powerful tarot. Here the tarot is a tool for praxis therapy, a thing to facilitate the process of 'individuation' (Gad 1994), an instrument capable of "heal[ing the] human psyche and lift[ing the] human spirit" (Semetsky 2010b, 59), and offering transformation and transcendence (Bala 2010). Its efficacy is established by linking it to psychological theories of 'abjection' and archetypal psychology (Semetsky 2000). We can use individual archetypes to facilitate self-journey and awareness, reading deep archetypal significance from them (Nichols 1974). In certain branches of psychology, the tarot is even more than mere individuation. Its utility is extended into the world of semiotics and child psychology (Jayanti 2004). Some see tarot as a tool to teach children the "three I's" of "informal education": intuition, insight, imagination (Semetsky 2011a), or even as a powerful therapeutic tool, a reflection of the four gateways of childhood, bursting with deep psychological meaning, a divine reflections of deep psychology so powerful that it might help heal the inner child and rework toxic socialization. As Jayanti $(2004,8)$ notes:

To conclude, [because] so many of us were brought up in dysfunctional families...a great need to re-habituate or re-parent...ourselves has arisen. Many types of work geared to reclaim and heal the Inner Child have become available to answer this need. The ancient Qabalistic tarot and Tree of Life have offered the tools with which to do this type of transformational work.

According to Semetsky (2011a, 252) "The tarot images that are laid down in a particular pattern are thereby 'selected' by soul, by the unconscious, and cannot be considered random." In this way, the tarot becomes a kind of mystical Rorschach, allowing an individual or therapist access to deep levels of meaning in the collective memory pool for the purposes of spiritual work, meaning, and mythological revelation (Semetsky 2009; 2011b). "When symbolically represented in Tarot images, the transcendental realm of the psyche is being brought, so to speak, down to earth by virtue of its embodiment in physical reality." (Semetsky 2010a, 110 , emphasis in the original). In line with this line of thinking Nicholson (2003) uses the tarot to illustrate deep wisdom of feminist theology, and Santarcangeli $(1979,33)$ informs us of the deep cosmic 'wisdom' of the fool. If you believe the psychologists, pregnant with meaning, the 
tarot is a teacher of lessons and a font of cosmic/genetic/racial wisdom and memory.

\section{The Reality}

At this point the question is begged, what is it about the tarot that has made it into such a special tool for so many people. More to the point, why did a simple game of cards become the magical mystery tour de force that it is today? The first clue to unraveling 'the mysteries of tarot' comes in the origin and time line of the tarot deck. The tarot's origins can be precisely pinned down, specifically to the royal courts of fifteenth century Italy (Dummett 1980). After that date, there are no references to the tarot as anything other than a game (or a vice) until just before the French Revolution (1789 - 1799), when Protestant priest and Freemason Antoine Court de Gébelin published (in 1781) volume eight of Le Monde primitif (Decker, Depaulis \& Dummett 1996). In that volume are two essays, one by de Gébelin, and the other by M. le C. de M. ${ }^{2}$ expounding on the mystical, cabbalistic, astrological, and Egyptian significance of the fifteenth century Italian tarot (Dummett 1980).

Subsequent to the publication of these essays, the tarot was picked up by famous cartomancers, including Etteilla and Mlle. Marie-Anne Adelaide Lenormand, and later still, commented on by magical (and Hermetic, Rosicrucian, and Masonic) luminaries such as Eliphas Levi, Arthur Edward Waite, Aleister Crowley, and so on (Dummett 1980; Decker and Dummett 2002; Farley 2009). During the period of effusive imposition of occult significance, the tarot came to be associated with ancient Egyptian high priests, ancient cabbalistic Jews, Hermes Trismegistus, the divine Lux (light/spirit) behind reality, the Gypsies (who were said to be roaming Egyptians), the divine name of God (the Tetragrammaton), and the Sephiroth (divine emanations). It was, so they said, created under the direction of Hermes, devised by seventeen magi, and written on magical leaves of gold (Dummett 1980, 107). Originally constructed as a game, or a book of allegories, the tarot was co-opted by esoteric/ secret societies, became associated with their 'secret knowledge,' and eventually came to inscribe not only their magical 'initiation rituals,' but the magical path of the soul as well.

The question at this point must be, does the tarot contain esoteric truths from ancient Egypt? Is it a magical book of books? Did Egyptian

2. Court De Gébelin refers to the author of the second essay as M. le C. de M.***. As Dummett (1980: 105) notes, Robin Briggs identifies the contributor as Louis-Raphael-Lucréce de Fayolle, Comte de Mellet. de Fayolle was a brigadier in the cavalry, a governor, and an "unremarkable court noble." 
high priests and ancient high gods write the divine wisdom of the cosmos onto the gold leaves of tarot? The answer to that is an unequivocal, no. According to three of the most authoritative figures on the subject, there is no historical basis to any of the ancient (or modern) occultists' claims about the significance of the tarot (Decker \& Dummett 2002; Farley 2009). In fact, according to Dummett (1980), historical claims that the tarot is anything other than an Italian game of trumps are an uninformed, esoteric mish-mash. The question isn't how to uncover the secret mystical knowledge, but rather "Why did a simple pack of cards come to take on such magical and mysterious import?" This sociological question remains largely unanswered (Decker \& Dummett 2002, 315).

\section{UnRaVeling the Mystery}

The first clues to unraveling the 'mystery' come from the temporal location of its emergence as a divinatory tool, specifically, during the French Revolution. At that time, traditional power structures were crumbling and New World industrial capitalism was emerging. The popular mind sees this period as one of general emancipation, but as any sociologist will know, the history of the French, English and Dutch revolutions and the emergence of industrial capitalism is not the history of the end of class oppression. Instead, it is the history of the replacement (more or less) of one ruling class with another. During the transition, feudal relations of power, feudal ideological institutions, and feudal systems of control were replaced with industrial ones.

The story of this transformation is understood, at least in general terms, as a disciplinary revolution. Between the eighteenth century and middle of the nineteenth, Western institutions changed dramatically (Kieser 1998) and new forms of behavior were required if industrial capitalism was to survive and thrive (Weber 2003). It essentially came down to the creation of new kinds of authority, and new power relations, as economic, productive, and social crises brought the old feudal order to its knees (Dobb 1972). It is, in short, about the creation of modern corporate/ bureaucratic control structures, fitting workers and middle management with the executive branches, and creating the well-oiled capitalist machine we have today (Barnard 1968). In the context of the disintegration of traditional organizations and traditional authority structures, the issue was one of authority, command, control, and legitimacy (Weber 2003), especially in emerging industrial production. Modern corporations and bureaucracies have top-down executive control and established disciplinary procedures, but these things would have been 
absent at the cusp of the revolution. At that time, there would have been an obvious need to create new organizational structures and civilizing influences (Elias 1994), and of course, that is what happened. It is a common story in sociology with the rise of the Protestant ethic (Weber 1987; 2003) and the dispersion of 'institutional strategies' for maintaining collective discipline throughout Europe (Gorski 1993, 266).

In the context of 'institutional strategies' for maintaining collective discipline, Freemasonry and other middle-class "men's huts" (Jewkes, $2005,47)^{3}$ can been analyzed sociologically. According to Jewkes (2005), freemasonry is part of a male bonding ritual, characterized by hierarchies and exclusions, and that reproduces and reaffirms patriarchy, unequal power relations, and 'male' hegemony. Jewkes' comments are relevant here, not so much for the Masonic performance of patriarchy, but for the way the Masonic universe reinforces and, more importantly, re-creates power relations, not in a feudal way, but in a bourgeois one.

When they were first introduced, Masonic lodges were safe places to explore, proselytize, and convert people to the new social order. "It was in the lodges and through them that the bourgeoisie acquired a social form of its own. In imitating both its mystery won a place beside the ecclesiastical mysteries and the arcane politics of States" (Koselleck 1988, 72, quoted in Horn 2011, 111). According to Kieser (1998, 47), Freemasonry was part of the shift in control and disciplinary strategies from feudal organizations, such as guilds, which "encompassed" members "in total") and organizations that required less complete forms of immersion (i.e. pre-modern bureaucracies). In this context, Freemasonry was an ideological and pedagogical control strategy, helping to facilitate not only required changes in behaviour, but also the development and acceptance of modern command and control structures. As Kieser notes:

The shift from estates to organizations necessitated enormous changes in the individual's behaviour. Today, organizational behaviour has become so common that we are no longer aware of the amount of learning about new behaviour that members of the early organizations had to manage.

3. Men's huts are "where those men who have earned the right to call themselves men, or are in the process of attaining this emblem of privilege, gather" (Remy 1990, 45, cited in Jewkes 2005, 47). Jewkes goes on to say “[m]en's huts for the middle class are institutions such as golf clubs, gentlemen's clubs, and Freemason lodges, while working class manifestations include pubs and betting shops" $(2005,47)$. Men's huts exclude women and "uninitiated" men. The metaphor derives from the physical men's huts found in many huntergatherer societies. Anthropologists have found that the greater the distance (physical or social) between the men's hut and the rest of the village, the poorer the relative position of women within the society (see, for example, Spain, 1992). 
For example, in organizations, they had to accept a person as a superior for the simple reason that this person was appointed as a superior. The superior could be younger, less educated, of a lower social status, less skilled - none of this mattered; as a subordinate, one had to accept his or her orders. On the upper levels of an organization, the member also had to be able to make decisions according to the rules sine ira et studio (without ire and passion), even if, as an individual, he or she would have decided differently. In general, as a member of an organization, one has to do things for an organization according to plans, procedures, or orders that, as an individual, one would tend to reject. In the 18th century, very few people were able to exhibit a behaviour that was appropriate for organizations and even fewer were capable of designing organizations. $(1998,47)$

In the context of the disciplinary revolution, Gorski (1993) notes two important features of the new organizations: an ethic of social discipline and surveillance. Members of modern organizations enter into a disciplinary community with all the standard features of modern control, including enclosure, partitioning, ranking, organizational rules, etc. (see, for example, Foucault 1975). Furthermore, the ethic of social discipline requires mutual (later technological) surveillance. Freemasonry was very popular in the late seventeenth and early eighteenth centuries, a time when feudal methods of control and discipline were dissipating and new forms were required. Freemasonry provided discourses of authority, a disciplinary ethic, and provisions for mutual surveillance and social discipline, all rooted in and inspired by Calvinism and ascetic Protestant ethics (Gorski 1993). Kieser (1998) provides a revealing translation of several masonic speeches of the era. Freemasons saw themselves as 'impressive men,' conscious of their role in the formation of new social orders, and actively involved in steering its emergence. Freemasons had a moral duty for mutual education in temperance, politeness, prudence, perseverance, and other characteristics suitable to a new and emerging bourgeois society. Freemasons were admonished to be active, to have a strong work ethic, and to engage themselves in useful labour, all very valuable advice for anyone seeking entrance into the power centres of the emerging middle classes.

Lodges were thus organizations that enabled their members to develop precisely those skills they would need as capitalism developed. Lodges constructed the first hierarchies ${ }^{4}$ divorced from feudal tradition,

4. Masonry has a "trigradal" system, entered apprentice, fellow craftsmen, and master (Knoop \& Jones, 1947). This three tiered division, which emerged as Freemasonry passed from operative into speculative forms, reflect the Capitalist social classes, lower, middle, and upper, and also the worker, middle management, and executive branches of modern organizational bureaucracies 
basing advancement not on 'the dignity of birth,' but on the acquisition of key organizational and moral skills, such as self-discipline, reliability, loyalty, and subservience to the command chain, and this was true even for nobles (Manheim 1979, cited in Kieser 1988). Nobles entered lodges as well, and they did so as a way to transition themselves from old power relationships into new ones. Lodges offered a way for old layers of nobility to mingle with emerging industrial elites (Kieser 1988). Similarly, Freemasonry offered the upper bourgeoisie fulfillment of its need for prestige and recognition. In this way, secret societies, as they initially emerged, helped to bridge the social gap (Kieser 1988). Perhaps most importantly, Freemasonry facilitated the development of a morality that would facilitate business relationships (Schindler 1982, cited in Kieser 1988). In this regard, Freemasonry can be considered a brilliant and self-conscious strategy for lubricating the transition from and old to a new world order - it helped create new modes of discipline and authority, and new power structures, all the while co-opting potential resistance (by incorporating feudal authority) and obscuring the intent and outcome of its operations.

The ideological, political, and social functions of the Freemasons (and other secret groups) have long been established. ${ }^{5}$ The question now becomes, "What does all this have to do with the tarot?" The answer is, "Everything." From almost the beginning, the tarot has been an essential part of ideological indoctrination in secret brotherhoods, and a tool useful for facilitating the mutual education of the emerging social elites. Indeed, new speculative lodges were barely open a day before tarot became incorporated. The moment of creation of the 'occult tarot,' and the principle author responsible, are highly revealing indicators. As Dummett notes:

The entire occultist tarot tradition stems from the work of Antoine Court de Gébelin (1719 - 1784), a Protestant pastor, Freemason, and savant.

5. Interestingly, the story of the Masonic men's hut as tool of ideological indoctrination of the emerging elites fits well with the historical transformation that occurred in Freemasonry during the 18th century. Prior to about 1740 Freemasonry was nothing more nor less than a craft union, functioning to organize stone workers, protect their interests, and protect the craft (Knoop \& Jones, 1947).In the 16th and 17th centuries however Freemasonry was transformed from "operational" to "accepted," and finally to a "speculative" secret society. This transformation occurred as the doors of the organization where thrown open to individuals outside of the craft itself. It began when Freemasonry began to "accept" members as brothers despite the fact that they were not stone masons. Initially acceptance was based on an expressed interests in architecture or engineering (both loosely related to craft working) but later, as elite, nobles, merchants, and others were "accepted," the pretense was dropped altogether. At a certain point, 1740 to be specific (Knoop \& Jones, 1947), speculative Freemasonry, a Freemasonry based on the creation of legend, mystery, and "esoteric" secrets, was born.. 
Born in Geneva, he was the son of Antoine Court, the most prominent French Protestant pastor of his day, and lived in Switzerland until he was 40. (1980, 102, emphasis added)

Court de Gébelin initiated the idea of the occult tarot. Following him, the idea of 'the tarot as occult masterpiece' was extended by Freemasons, clerics, and other members of the emerging elite (Dummett 1980). The ideological imposition reached a sort of culmination with the work of prominent Freemason, A.E. Waite in the early twentieth century, but even down to this day tarot decks are regularly linked to secret societies. ${ }^{6}$ For example, authors such as Jayanti (2004, v) reference well-known Freemasons like Paul Foster Case as teachers. And lest one doubt the insertion of tarot into ideologies of hierarchy and control, Jayanti unselfconsciously discusses major modern decks as derived from elite organizations participating in the 'spiritual hierarchies' (read 'elite hierarchies') of this world:

The true tarot decks that have been published by authentic Mystery Schools, such as the Order of the Golden Dawn of England with the Rider deck, and the Builders of the Adytum of the US with the Case deck, are true in that they most closely approximate the unpublished tarot of the Inner School, the Spiritual Hierarchy of the world (Jayanti, 2004: ix).

Of these 'inner schools,' Lachman's (2011) remarkably forthright, if not particularly introspective, comments are instructive as well:

The Secret Chiefs, the Hidden Masters, the Inner Circle, the Illuminati, the King of the World: we know them all today, perhaps in different forms and perhaps by different names. But we know them. They are the ones in control. They are the ones behind the closed doors and within the locked rooms. They are the ones with the secret knowledge, who speak a secret language. They know the magic symbols that unlock the gates that lead to worlds beyond our own. They have passed through the trials and ordeals of initiation. They have found the Holy Grail, the Philosopher's Stone, the Emerald Tablet, the dreaded Necronomicon and the lost continent of Atlantis.

The question now becomes, why choose tarot for this purpose and why incorporate it as a tool of indoctrination when it was merely a card game at the time? The answer, although lost in the mists of time, likely revolves around (a) the allegorical meaning of the images, a meaning linked to the Italian courts of the fifteenth century, (b) their suitability

6. For a more detailed overview of the history of the occult tarot, see http:// en.wikipedia.org/wiki/Divinatory tarot (retrieved April 2, 2013). 
as an imaginative device capable of absorbing additional meaning, and (c) their suitability for ideologically impregnated drama. As Dummett (1980) notes, the original tarot decks were painted for members of the royal elite. As Farley (2009) discovered, the images themselves were representative of the life and times of important noble families. Thus the images incorporated themes that any sociologist would recognize as representing elite life, elite priorities, elite ideology, and elite spirituality. ${ }^{7}$ There is a Court Fool, for example, and a Court Juggler. The authority of the state and church are clearly represented in the Empress, Emperor, and Pope cards. There's a Chariot carrying the king, a Hermit (a monk perhaps), an angel of Temperance, and the Justice of the royal courts. Death, a common fact of life, is represented, as is Love (and marriage). Even the Christian last Judgement, a cautionary tale if there ever was one, is there.

Figure One: The Emperor and Hierophant (Pope) from the Rider-Waite Deck
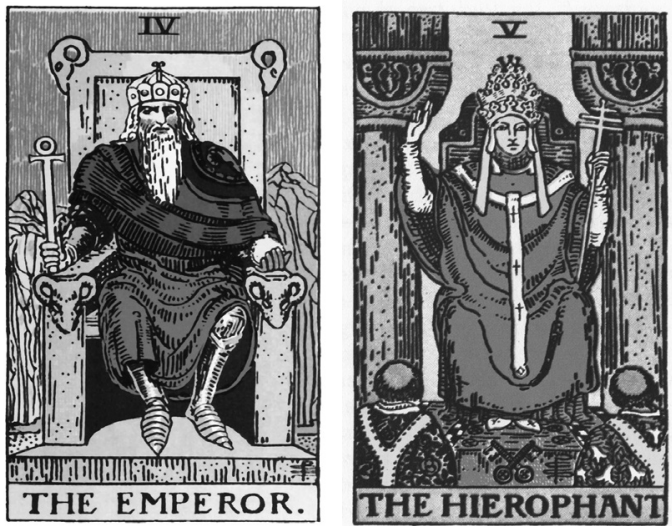

The presence of elite ideology and practice in the already existing tarot deck would likely have been attractive to the Protestant clerics and Freemasons who co-opted the deck. After all, they were demonstrably members of the elite already. More attractive perhaps would have been the opportunity to read in additional meaning. Images are worth a thousand words we are told, but what words those might be are often a matter of

7. See http://en.wikipedia.org/wiki/Tarot de Marseille for a representation of the Tarot de Marsailles, one of the earliest, and certainly the most influential, representation. [Retrieved April 3, 2013] 
imagination and interpretation. As recognized by some Jungian psychologists (see, for example, Rosengarten 2000), tarot images (like any good images) are artistic devices that can carry significant additional meaning. It took only a few years before the originators of the occult tarot had impressed dogma, magic, and mysticism from the Western esoteric traditions upon the tarot. ${ }^{8}$ Soon tarot cards conveyed cabbalistic, astrological, alchemical, and gnostic import (Decker and Dummett 2002). The allegorical bed of the tarot provided a fertile ground within which to plant the seeds of a new, post-feudal ideology.

Finally, tarot was probably attractive to emerging elites because of the initiatory function it could come to serve. Versluis (2007) notes that initiation is a crucial part of the entire Western esoteric tradition. Initiatory rights can be traced to antiquity and are to be found, for example, in the early Eleusinian mysteries, where initiates were called epoptes (i.e., those who behold). Epoptes were served by the hierophant, the one who reveals the secret truths. Interestingly, Plato's Allegory of the Cave can be read as a tale of initiation:

"This famous Allegory of the Cave reveals themes that reappear throughout the subsequent history of Western esoteric traditions, above all, the conflict between the uninitiated and those who have eyes to see" Versluis $(2007,16)$

Initiation is a form of secret baptism, and is understood as a 'revelatory' process. The propaganda of initiation holds that, in an initiation experience, the seekers' eyes are opened, they are bathed in light, and access to the liminal realms of knowledge are opened to them. Initiatory rights are indoctrination ceremonies where elite ideology is impressed upon the epoptes using common ideological and emotive devices. In this regard, the tarot came to provide a sort of prototypical initiatory experience, where meaning and message could be conveyed under the cloak of ideologically pregnant image, ritual, and drama. These comments are not original. In fact, members of elite organizations understand perfectly the goal of drama in evoking emotions and controlling thought. As two magicians from the modern Order of the Golden Dawn admit, it is all about manipulating emotions to deliver "messages" to the initiates:

Such dramas were intended to captivate the senses and tug at the emotions as they retold the sacred legends and delivered important teachings to devout followers. Then, just as now, ritualists employed theatrical props,

8. As noted by Versluis (2007), these are Hermeticism, gnosticism, Jewish mysticism, and Christian gnosis. 
special effects, symbolism, gestures, speeches, and other elements of performance to have the greatest visual and emotive impact on their audience and to convey the desired message or catharsis of feeling. (Cicero and Cicero 2012, 108)

In a word, brainwashing. While neither the Freemasons nor the Rosicrucians used tarot as initiatory vehicles at first, by the middle of the eighteenth century, the tarot became the vehicle for initiation into 'the mysteries' (Dummett 1980) ${ }^{9}$

Of course, just because the tarot was attractive did not make it an automatic tool for ideological manipulation and control. Work had to be done on this game to establish its 'occult authority'. Elite authors (many of them high-level Freemasons) throughout the eighteenth, nineteenth and twentieth centuries established the authority of the tarot in a curiously anti-intellectual fashion, citing not the actual history of the deck (which could never have supported their claims to its occult authority) but instead pointing to a fabricated history of legend ${ }^{10}$ based on fanciful and metaphysical imagination. They also exploited incestuous citation practices (citing one another's works as authorities), and also relied heavily on what Dummett $(1980,124)$ calls 'false ascription.' False ascription is a rhetorical strategy designed to bolster authority of a phenomenon by attributing it, or commentary on it, to some form of authoritative source. In the case of the tarot, the authoritative source could be an ancient philosopher, a mythological figure, an esoteric tradition, or whatever else could be conceived of. Over and over, we find authors of tarot books and cards making outrageous claims about the deck, developing false lineages, attributing it to mythological forces, making

9. The Brotherhood of the Rosy Cross is a mystical society that originated in Germany in the early seventeenth century. Rosicrucianism has always been an esoteric philosophy, but it was also associated with Protestantism and concerned with empiricism rather than dogma. It is considered to have been an early influence in the development of the Royal Society, which was established in London in 1660, and devoted to the exploration of science and natural history. Freemasonry incorporates many Rosicrucian principles and rituals. For a discussion of the origins and influence of the Rosicrucians, see Yates (1975).

10. The creators of the occult tarot were not the only ones creating false histories and "legend." As Knoop and Jones (19747) note, early speculative Freemasons in the period between 1712 and 1740 spent a lot of time constructing the legends of Freemasonry. Interestingly there is, at least amongst Freemasons of the time, a recognition that the legends were legends and not to be taken as serious historical accounts (Knoop and Jones, 1947). This is a fact lost on many modern tarot aficionados who, even when presented with scholarly evidence to the contrary, continue to maintain the deck has an ancient Egyptian, hermeneutic, or gnostic significance. 
ridiculous epistemological and ontological claims, and generally going to great lengths to ignore history and establish the authority of the tarot. ${ }^{11}$ It is the argument of this paper that it is precisely because the tarot was understood and developed as a device for ideological indoctrination that the history of the tarot was so blithely ignored and a new one built. One could not build a powerful tool for indoctrination on the fact that the tarot was a simple card game invented in the Italian courts - that would immediately raise doubts about authority, and concerns about ideological content. Thus, lies where told, and authority built, by claiming great antiquity, Egyptian roots, mythological origins, gypsy diaspora, and so on (Farley 2009). In this way, the occult authority of the deck was bolstered at the same time that its ideological content became 'veiled.' It is notable that the 'veil' was not something of divine origin, rather imposed by the conscious strategies of the Freemasons involved.

\section{The IDEOLOGY}

For five centuries or more tarot cards have been used in Europe, ostensibly for games and fortune-telling, but really to preserve the essentials of a secret doctrine. They form a symbolic alphabet of the ancient wisdom, and to their influence upon the minds of a few enlightened thinkers we may trace the modern revival of interest in that wisdom. (Case 2012, 5)

The question remains, "What exactly is the ideology embedded in the tarot?" We might think that uncovering this ideology would be a major challenge, especially since Western esoteric traditions are, by and large, secret traditions, but it is not that hard, for several reasons. For one thing, and as contradictory as it might seem, modern esoteric traditions are by and large written traditions (Versluis 2007). Ideology is imprinted in words and images, and it is often very easy, if one has the right perspective (the "eyes to see" as they say), or can make a simple intellectual connection, to read the ideology directly from the image or text. Consider the Wheel of Fortune card, which is typically said to indicate the 'kingdom' or, more directly, the world around us. It is an image of

11. A representative sample of this charade is provided by Mathers (1888), a Freemason and one of the original members of the Hermetic Order of the Golden Dawn. One need only read two or three pages of the online text to see the absurdity. See http://www.sacred-texts.com/tarot/mathers/index.htm (retrieved April 3, 2013). See also Paul Foster Case (2012), who embraced the mythology with both arms, and extended it back into the ancient Vedas, holding it up as representative of universal truths buried deep in the heart of the tarot. 
reality, often with karma invoked. It is the expression of spirit, a working out of the true law of the universe, a perfect representation of divine providence, or as Paul Foster Case says, a representation of "spirit in self-expression":

The tenth trump, the Wheel of Fortune, is Malkuth, the Kingdom. As the parables of Jesus plainly show, that Kingdom is not a state of life after death; nor is it, except in a very limited sense, a social order. It is the method of Spirit in self-expression; and because cyclicity is characteristic of that method, the tarot symbolizes the Perfect Law as Buddha did, by a Wheel. (Case 2012, 32)

It is quite interesting that Case drops the word 'social order' into his description of the meaning of this card. What a social order, however limited, has to do with the self-expression of Spirit is unclear, but it is apparently related. Case of course doesn't bring out the nature of the social order in his text. This is a "secret" tradition after all where the inner truths of the hearts of men are drawn out in the hidden spaces of the temple alcove. The meaning of the card, and the nature of the "social order," is available however in the visual imagery of the card with clarity, precision, and dramatic oomph. Consider the Golden Dawn image below.

Figure Two: The Golden Dawn World Card

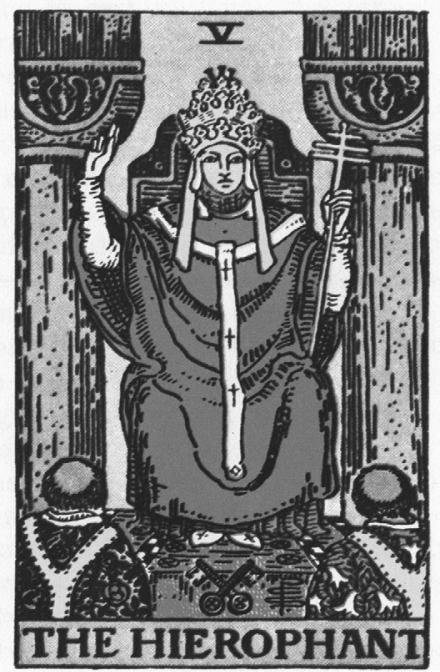

The social order that Case is referring to is quite plain to see in the card above. Nature below, the gods above, and the wheel of life's cycles of (birth and rebirth) in between. This is an elite social order and this 
elite social order is embedded in Western esoteric traditions all the way back to Plato, as Versluis notes of his Republic, "The Republic also resonates with the recurrent idea of creating a spiritual utopia governed by an enlightened elite, a concept found much later, for example, in the Rosicrucian movement of the seventeenth century" (Versluis 2007, 16). Looking at the card it is hard not to see the enlightened spiritual elite governing the unenlightened and primitive masses. The ideology or 'message' embedded in the card is something that should be familiar to any second year sociology student: the card represents a two-class social system, and a not very pretty one at that. The upper class is royal and regal, while the lower class is unevolved, ape-like, and clearly passive. The Golden Dawn card is remarkable not only for the 'hide in plain sight' way that elite ideology is presented, but also for the remarkable way the ideology is accepted as part of a package of divine revelation, of spirit expressing itself in the Kingdom. Elites are justified to rule because they have access to the 'light,' they are 'evolved,' and so on. The rhetorical turn (reinforced by a visual turn, crucial in pre-literate societies) represented here should be apparent, and a visceral reaction may even accompany our realization that the divine, magical, Egyptian, Vedic wisdom represented in this card is nothing more than a prettied up version of Catholic doctrine concerning the divine right of kings. Social class, hierarchy, command, control, privilege, and the unequal distribution of power, so typical of the 'class struggle' of this world (Marx 1848), is writ large on this card.

Another reason that is it not hard to 'read' the ideology of tarot is because, at the beginning of the twentieth century, the 'secrets' of esoteric elitism were fully exposed to the mass consciousness (Decker and Dummett 2002) and subsequently penetrated into, and become a part of, the ideological fabric of this planet. Members of the men's huts of the time, most notably Crowley and other members the fraternal organization he founded, made it a point to expose the 'secret teachings' to the outside world. A scandal at the time, Crowley irked members of Hermetic Order of Golden Dawn when he self-consciously set himself, and other members of his very own secret club, as the revealers of all the secrets. Crowley created the journal The Equinox, and then subsequently published Golden Dawn secrets and rituals in his open esoteric journal. ${ }^{12}$ He sets the agenda in the opening editorial of the publication, though not

12. All issues of the journal are available online at http://hermetic.com/crowley/ equinox/ (retrieved April 3, 2013). 
without first casting standard aspersions on the 'multitudes' (i.e., lower classes) of the world. ${ }^{13}$

With the publication of this Review begins a completely new adventure in the history of mankind. Whatever knowledge may previously have been imputed to men, it has always been fenced in with conditions and restrictions. The time has come to speak plainly, and so far as may be in the language of the multitude. .

But the Brothers of the A $\therefore$ A $\therefore$ make no mystery; They [sic] give you not only the Text, but the Comment; not only the Comment, but the Dictionary, the Grammar, and the Alphabet. (Crowley 1909, 1)

And so the 'revelation' begins. However, it is not a revelation of high spiritual truths, but an exposure of elite ideology and elite government. The essay that follows Crowley's editorial [by Councillor Von Eckartshausen (1909)] is a veritable map of 'spiritually enlightened' government over the masses. The document exposes elite justifications for discipline and control, justifications given in both standard 'Christian' terms (i.e., only a few people are chosen, only a few may access the light) and newly minted scientific coinage (with references to evolution, strength, and fitness.) It is also interesting for the open way it discusses inner circles and secret governments, occult group meetings, strategies for co-opting new members into the hierarchies of the world, and even political action. Of course, we should be cautious about descending too far into the paranoid hyperbole of conspiracy. But even so, the nature, scope, and political and ideological activities of the elite are well understood by sociologists (see, for example, Millar and Dinan 2007). The new revelation here is an esoteric mechanism for delivering elite ideology, a mechanism that, if our lack of understanding of it is any indication, has been surprisingly efficacious.

A third reason that 'reading' the ideology in the cards is not that hard is that the ideology itself has spread out into established scholarly work about tarot. Scholars themselves, unwittingly or deliberately picked up the ideology 'revealed' by Crowley as he stepped us all into the new

13. Let the secrets out? Why? Not to foment the collapse of class structure, but because the ideology had become refined enough to be exposed to the mass mind. With publication of A.E. Waite's tarot deck in 1909, the Masonic ideology of the tarot has moved into the popular mass conscious, where it exerts ideological influence over the masses, just like any other religion or spirituality. Almost all modern tarot decks derived from Waite's extremely popular deck (Farley, 2009). Indeed, it is hard to find a deck that does not have characteristic cards of the Waite deck, and therefore, Masonic influences. 
'aeon.' And they do it in the same obfuscatory way, claiming ancient perennial spiritual wisdom underlies the sacred images of the tarot (e.g., Place 2005). Jungian psychologists pick up where occult patriarchs left off, attributing all sorts of magical, archetypal, and semiotic wisdom to the deck. Nichols (1980), a student of the C. G. Jung Institute in Zurich repeats many of the clichés of the esoteric brothers (though embellishing them with psychobabble to make them look different), and importing deep undercurrents of elite ideology and justification.

Reading the ideology from the cards is not that difficult. No doubt there are undercurrents that require deeper analysis, but in many cases the representation of elite authority is plain to see. There is an Emperor and an Empress, a Pope (Hierophant in later versions), an Angel issuing a statement of judgement, and so on. The better question for us is, "Why do so few people actually see it?" Why does popular commentary on the tarot accept elite justification, ideology, and fanciful legend, rather than taking a more critical stance? The answer to that question is more complicated. A thin spiritual patina complicates the commentary and the imagery, and obscures the ideological content. This spiritual patina works to deflect attention. In addition, our eyes are blinded to the plain truth by a rhetorical wall spread by the brothers. Those who seek to understand tarot are inevitably greeted with the anti-intellectual, anti-historical, superficially authoritative, rhetorical bulwark created by Freemasons, Rosicrucians, and Golden Dawn mages. One might doubt the initial magical, mystical, spiritual important of the deck as represented by members of these men's huts, but then encounter a Jungian psychological's modern rationale and explanation that obscures ideology in a new way.

There are other challenges. Writings on esoteric topics are often filled with obtuse, complicated language filled with "tortuous.... correspondences" (Dummett 1980, 130), arbitrary associations, and grammatical complexity horrid enough to invoke comment and condemnation, some of it tongue-in-cheek ${ }^{14}$ from scholars. Pompous verbiage is a rhetorical strategy, a verbal sleight-of-hand trick, designed to make a text appear authoritative. It fools the naïve outsider in the same way that Dorothy was initially fooled by the Wizard of Oz. It also makes actual investigation difficult. How can one question the authority of a sacred text if one cannot decipher the verbiage? Crowley's ponderous exposition of the secrets of Enochian magic (Crowley 1912b; 1912c) are illustrative, but not the only one. The type of discussion presented in the work of the

14. See for example my definition of Egotistical, Polly-syllabic, Multi-metaphoric, Obfuscation (EPMO) http://www.thespiritwiki.com/index.php/EPMO. 
'brothers' may be found the work of spiritually inclined (but ideologically näive) psychologists as well (see, for example, Wilber 1996; 2000).

\section{Discussion}

The intent of this paper is not to expose in detail the underlying ideology of the tarot major arcana, that is the task of a subsequent paper entitled The Ideology of Tarot (Sosteric, in progress), but rather to demonstrate that such work is both needed and possible. In other words, this article has tried to establish the need for a sociology of the Western tarot specifically, and a sociology of the occult more generally. This Sociology of Tarot includes a sociology of how those who practiced tarot used the decks in ways that related to changing relations of class, discipline, power, and ideology. It appears that tarot was invented as a deck of playing cards, reflecting the life and times of significant Italian families, but became implicated in the double revolutions that collapsed structures of feudal authority, and legitimated new systems of social authority and discipline. The tarot deck was a useful tool for this purpose because the imagery was already linked to elite practice (having been invented in the courts of Italy), already had suitable iconography (kings, queens, and popes), was plastic and could be 'imprinted' with additional symbolism, and eventually became used as an initiatory device in secret societies and new religious sects emerging at this time. Work to establish the occult authority of the deck was accomplished by prominent Freemasons, clerics, and members of the transitioning elite. The net result was a deck of superb ideological brilliance and utility, capable not only of indoctrinating members of secret organizations, but also of imprinting mass consciousness with elite ideology.

Although one might initially feel that a sociology of the tarot would only be of historical interest, that is not the case. The movement of tarot ideology into the mass consciousness, as encouraged by Crowley and his brothers for example, has left an unchallenged (and potentially quite significant) ideological imprint. Coupled with the recent proliferation of superstition, ignorance, and irrationalities of modern society as noted by Bauer (2011), and the uncritical way tarot aficionados (even academic ones) take up the ideology (e.g. Place 2005), the social impact of tarot in contemporary society may be taken too lightly. Doering-Manteufell (2011) found a dramatic spread of superstitions that uses modern communication technologies as a means to proliferate occult (read ideological) practice. This is particularly evidenced in the proliferation of tarot decks. Today literally hundreds of tarot decks are in print, all representing 
the author's particular views, but almost all of them echoing iconic Masonic imagery and interpretation (Farley 2009). More than ever, sociological analysis in the occult tarot specifically, or occult phenomenon more generally, seems warranted.

Sociological investigation would include analysis of ideology and control that might explore links between the tarot and the ideological importance of religion (Weber 2003), or disciplinary control strategies identified by Foucault (1975) and others. There are also dialogic questions about the rhetorical strategies used not only to obscure the true nature of elite ideology embedded in the tarot system, but also to lend occult and spiritual authority to the tarot (Fairclough 2001). These strategies have only been touched on in this paper, but other strategies are evident and need to be exposed. ${ }^{15}$ Finally, the psychology of the tarot, specifically its use in dramatic ritual and initiation pageantry, and its utility as a device of indoctrination, are also interesting questions worthy of sociological examination.

It is also useful to note that the history of tarot and the occult are not just class histories, they are histories of patriarchy and racism. As noted earlier, sexism is imprinted on the very structure of men's huts, and for all the mystical wisdom offered up, the sexism is prominent and often offensive, especially in dominant figures like Aleister Crowley [see for example the opening words of the Crowley editorial in the inaugural edition of Equinox (Crowley 1912)]. Racism also figures in the principal texts of theosophical movement [see Blavatsky 1888; Besant 1907 and 1911), and Besant \& Leadbeater (1913)] where doctrines of spiritual progress, reincarnation, and karma are based on racial frameworks and derogatory characterizations of "non-Aryan" racial groups (Staudenmaier 2009, 52). Even contemporary Masons exclude women from consecrations of their lodges. In this context, it is important to point out that in the Masonic tarot, the Fool (the tarot 'signature' card representing the subject of the initiatory/evolutionary journey) is inevitably white, male, and young.

Berger (1969) assumed that Western societies would experience decline of spiritual and religious belief, and increased secularization.

15. For example, some authors will simply state truths as obvious, self-evident, and needing no authority, investigation, or elaboration. This questionable (and one would think academically transparent) rhetorical device is used, for example, by Place $(2005,75)$ who makes bald faced rhetorical claims about contested ideological frameworks without even attempting to back his statements up. For example, referencing the mystical vision of Levi, Place echoes elite ideology in the form of justifications of gender, and mystical cosmic dances between good and evil (Sosteric, unpublished), and asserts the veracity of said mystical truths as 'sophisticated mystical vision', self-evident, and requiring 'no authority to verify its timeless truth.' 
Berger himself has retracted the thesis, admitting that the secularization project has failed miserably, but rather than giving religion, spirituality, and the occult another look, Berger echoes earlier dismissals by rejecting spiritual and religious belief as "dripping with reactionary supernaturalism," and draws a boundary around its discussion (except as object of scholarly derision), excluding it as "beyond the pale at self-respecting faculty parties" (Berger 1999, 4). This is unfortunate. When talk of the sociology of occult means that you could risk the respect of your colleagues, scholars are likely to accept the canonical status quo and find other research interests.

This paper defends the need for a new sociology of tarot, occult, and ideology, and an open discussion of the significance and relevance of occult knowledge and practices. Note, however, that it is more than just social class, gender, ethnic, or ideological interest that is at stake here. There is a sociological question raised by all this: "Why do spirituality, religion, and the occult continue to hold such traction?" The implicit and probably unspoken (except at closed faculty parties) assumption of those who follow Berger probably invokes stupidity, incredulity, and irrationality, but this is hardly an explanation at all. People are not stupid and they do not, in general, believe things for no reason (Sosteric, Under Review). Better causes need to be established. Elites seem to believe in the tarot because it has been constructed by their members to reflect (and help distribute) an ideology supportive of hierarchy, privilege, and control.

Still others, like psychologists, have been critical of spiritual beliefs since Freud's (2012) dismissal of religion as an infantile delusion, yet some adopt the tarot as a fountain of mystical/archetypal wisdom in pretty much the same way as established by occult elites. There is also a very long history of very smart people being interested in religion, spirituality, and mystical phenomenon (Verselius 2007). William James, father of American psychology, took religion and mystical experience seriously not as an example of something else (e.g. as a class opiate, or as providing social solidarity, or as a sacred canopy, or as a stepping stone from our superstitious past into our rational future), but as something worthy of direct and engaged investigation (James 1982). Are these people stupid, irrational, and reactionary as well? Or, moving out of the realm of scholarly inquiry, why does the tarot remain so popular, or why do occult beliefs in general enjoy ongoing popularity. Can it all be dismissed as naivety or elite ideology, or is there something else going on with tarot and religion not yet identified by sociologists?

Hints may be offered here. In my sociology of religion class, for example, I explore the opportunistic nature of religion and spiritual beliefs. 
It turns out that when one examines the history of religion from a transdisciplinary perspective (Lundskow 2008), religious and spiritual beliefs are, as I argue in the course, opportunistic. That is, it is not just tarot that becomes a virtual Rorschach suitable for ideological impregnation by whatever 'special interest' group happens to come along; rather, spirituality and religion in general represent themselves as suitable for the projection of a political, economic, and other special interests. Religion and spirituality come to express - always and wherever they are found the social order, environmental realities, and even economic exigencies of a particular society at a particular time. Note however, that elites do not have unilateral control over the consciousness of the masses. Because religion is a resource, spirituality is a (arguably poorly) contested realm. It is the case that progressive or reactionary economic, political, and even gender interests may be inscribed into religious texts.

There is some work in this area. Owen (2004) has identified the spiritualism of late Victorian England as a practice and belief system outside the dominant patriarchy of the time, and other more contemporary examples may be found, as for example the grass roots, feminist compatible spirituality of Starhawk (Rigiglioso 2005). Religion and spirituality as resource may help explain why it remains a continual thorn in the side of the pundits of secularization. Nevertheless, despite the possibility of progressive spirituality, the question still remains, "Why do the masses accept these systems so uncritically?" or "Why do reactionary belief systems retain traction?" The persistence of the tarot may, as we have seen, be linked not only to elite machination, infantile fantasy, or opiate derived delusion, but also to basic human needs, needs that are not filled by the empty secularity of an 'enlightened' world (Sosteric 2013). In other words, there is a real psychological thing (a rational thing, an emotional, thing, even a human thing) going on here, and this thing must be taken at face value to be legitimate. Psychologists of the humanistic school have taken the thing seriously in acknowledging needs and motivations beyond food, water, and shelter, at least since Maslow, who formalized a 'positive theory of motivation,' recognized the 'need' for self-actualization and transcendence (Maslow 1943). Others also take it seriously as well, suggesting, for example, that people enter into esoteric 'cultic' communities (tarot being one, generic new age belief systems being another) for rational reasons; for example, because they are dissatisfied with solutions offered by religion and science (Jorgensen 1982; Laqueur 1996). In this context individuals may gravitate towards and accept tarot as the "bible of bibles" Freemasons make it out to be, because they are attempting to satisfy deep needs for spirituality and meaning 
(Sosteric 2013), needs not met, or met inadequately, through other avenues of spiritual or religious experience.

Finally, a third reason for continued belief in the occult, spiritual, mystical, esoteric, mystery traditions may be because they represent real experiences, real revelation, and real gnosis that undermine normal taken-for-granted reality of our regular 3D world (Lynch 1977; Sosteric Under Review). This suggestion may strike readers as scientific heresy, as indeed it is. But the alternative is to dismiss the collective experiences of billions of people throughout history who have believed in mystical realms beyond the mundane, but also the individual experiences of scholars who have had some powerful mystical experiences (e.g. Castaneda 1985). I find myself in this group of scholars whose interests were perhaps not initially scholarly, but mystical, and whose mystical experiences "broke open the head" (Pinchbeck 2003) and led them to question the materialist foundation of science. Such experiences are of deep scholarly interest (Forman 1999), and fit very well into the gnostic experiences reported by Western mystics down the ages (Versluis 2002).

Just as many other scholars use experience to develop scholarly insight, my experiences with tarot, mysticism, and gnostic traditions, have lead me to new sociological understandings. This raises scholarly questions, none of which can be served by out-of-hand, anti-scholarly dismissal. Western mystery schools, occult traditions, even established exoteric institutions like the Roman Catholic Church, all justify their positions, their tools, their bibles, their tarot books, by ascribing them to real mystical, magical, experiences. Christian are told to believe in the bible because it is the word of God, expressed through the mystical revelation of the prophets. Buddhists follow Buddhists tracts because they represent the mystical revelation of Buddha. Freemasons and Protestant clerics offer the tarot as the "bible of bibles" and support its authority in the same way, with claims for its antiquity, and linkages to the mystical experiences of authoritative personages (e.g. Hermes Trismegistus, the Egyptian god Thoth, etc.). This is nothing new. James (1982) said that all religions derive from somebody's mystical experiences. The point in this paper is simply that gnostic traditions, the words of the mystics, occult 'wisdom' traditions, 'mystical tools' like the tarot, deserve serious and critical inquiry and analysis as such, and there is good reason to apply sociological analysis here. People who have mystical experiences often impress upon them their social class, gender, ethnic, political, and economic biases. Nowhere do we find 'pure' gnostic truth. Everywhere we find opportunistic imprints on spiritual 'revelation.' The problem is, if we dismiss spirituality and religion as nothing more than ideology, as salve against existential crises, or as infantile fantasy, not only do we miss an 
arguably valid area of inquiry (spirituality and gnosis), we also leave a spiritual vacuum, an absence of sociologically sophisticated understanding, that has profound global consequences. As Butler (2006) notes, the Christian Right has been able to gain ascendency in global politics and culture precisely because the Left has abdicated responsibility for providing such meaning. We sociologists have seen the Wizard of $\mathrm{Oz}$, recognized him as a charlatan, and walked away. We have posted signs on the wall saying caveat emptor, but nobody seems to be reading the signs. Why do people continue to genuflect before the Wizard? There is a powerful need operating, and somebody always seems willing to fill it. The problem is that the people who move in, often do so without the best intentions (they have political, economic, gender and racial agendas), or without a sufficient degree of sociological, psychological, physical, chemical, even historical sophistication. The result is active imposition of ideology in the first case, or naïve adoption and unwitting propagation of ideology in the second. I would suggest a grass roots, sociologically sophisticated, spirituality, needs to be offered.

Alternatives already exist. Mentioned above is Owen's (2004) work, but critical, grassroots, spiritual turn already exists, as for example in the 'goddess movement' (Rigoglioso 2005, 173). Starhawk is an author actively involved in constructing the Goddess movement as a workingclass, grass-roots, politically sophisticated, active response to injustice, inequality, etc. It combines feminist theology and is interesting for the contested terrain that it represents in the attempt to distinguish 'authentic' spiritual paths from 'fluffy bunny' paths that are less substantive, more commodified and consumerised, and less serious (Coco \& Woodward 2007). The same could be done for tarot. I myself am developing, under a pen name, tarot images and archetypes that a) self-consciously break Masonic ideas, b) represent authentic spiritual gnosis (at least, in my view) and c) attempt to provide a critical, politically progressive, and sociologically sophisticated turn on spiritual/mystical thought in general (Sharp 2006), and the tarot more specifically (Sharp 2009; 2013; unpublished.). It is a response to the call Butler (2006) has made for a critical, substantive, sophisticated, and progressive spirituality, and that Swimme (1988) has made for stories that potentially save us from the increasingly disparate, and desperate, political, economic, and social state of affairs. The lesson of the Goddess movement, and the lesson of the Western tarot, is that there is a space to contest spiritual meaning and gnosis and, more importantly, there is a space (and a need) for sociologists to get involved. Exposing the roots of the tarot or other forms of mysticism in elite ideology is only the first step. The next step, for those so inclined, is to create new tarots, new gnostic wisdom, or at least to contribute to 
a respectful, but critical, turn. Head (2012), for example, embraces tarot as a way to bring depth to the experience of being queer. He uses tarot (admittedly the Masonic version) to embrace pride and justify queerness. The point is, the space is there. As sociologists we have but only to move in and fill it.

Filling in the religious, spiritual, and occult spaces will no doubt be a challenge, and perhaps one of the biggest challenges will be overcoming scholarly prejudice and actually taking the areas of interest seriously. There have always been attempts to dismiss the investigation of religion, spirituality, and other boundary phenomenon (Gyimesi 2012; Sommer 2012). Nevertheless, while skeptics certainly abound, research into boundary areas shows remarkable longevity (Kloosterman 2012) with notable intellectuals often coming down on the side of belief (Sommer 2012). No doubt there will be instances of dismissive ridicule (Staudenmaier 2009), even outright censure, but such reactions do not represent serious open minded scientific attitudes, but prejudice and fear of the kind associated with religion and dogma, and not science and truth. The whole thing has resulted in a "paucity of responsible scholarship [and] existing research in this area [that] is thin, often neglected, and of inevitably uneven quality" (Staudenmaier 2009, 48 - 49). For reasons outlined in this paper and more, it is a good time to begin alleviating this lacuna, especially now, as there is a growing recognition of the significance of the sacred, religious, boundary phenomenon which are no longer easy to dismiss as mere epiphenomena, but must be taken as significant, important, and in desperate need of analysis, attention, and understanding (Redden 2011).

\section{ACKNowledgements}

The author would like to thank Dr. Mike Gismondi and the anonymous reviewers for their helpful comments on earlier drafts of this article.

\section{REFERENCES}

Anon. 2012. Private Telephone Conversation with GG, Evangelical Christian.

Bala, Michael. 2010: The Clown. Jung Journal: Culture \& Psyche 4 (1): 50-71.

Barnard, Chester. 1968. The Functions of the Executive. Cambridge, MA: Harvard University Press.

Bauer, Martin W. 2011. Editorial. Public Understanding of Science 20 (3): 290291. 
Beeb, John. 2008. A tarot reading on the possibility of nuclear war. Psychological Perspectives: A Quarterly Journal of Jungian Thought 16 (1): 97-106.

Berger, Peter L. 1969. The Sacred Canopy. New York: Anchor Books.

Berger, Peter L. 1999. The Desecularization of the World: Resurgent Religion and World Politics. Grand Rapids MI: Eerdmans.

Besant, Annie. 1907. Study in Consciousness: A Contribution to the Science of Psychology. London: Theosophical Publishing House.

Besant, Annie. 1911. Man and his Bodies. London: Theosophical Publishing House.

Besant, Annie, \& Leadbeater, Charles. 1913. Man: Whence, how and whither. London: Theosophical Publishing House.

Blavatsky, Helena. 1888. The Secret Doctrine. London: Theosophical Publishing House.

Butler, Jennifer. 2006. Born Again: The Christian Right globalized. London: Pluto Press.

Case, Paul Foster. 2013. An Introduction to the Study of the Tarot. Gauteng, SA: Ancient Wisdom Publications (originally published in 1920).

Castaneda, Carlos 1985. Teachings of Don Juan: A Yaqui Way of Knowledge. Washington: Washington Square Press.

Cicero, Chic, \& Cicero, Sandra. 2012. The Essential Golden Dawn: An Introduction to High Magic. Minnesota: Llewellyn.

Coco, Angela, \& Woodward, Ian. 2007. Discourses of authenticity within a pagan community: The emergence of the "fluffy bunny" sanction. Journal of Contemporary Ethnography 36 (5): 479-504.

Collins, H. M. \& Pinch, T. J. 1982. Frames of Meaning: The Social Construction of Extraordinary Science. London: Routledge \& Kegan Paul.

Crowley, Aleister. 1909. Editorial. Equinox 1 (1): 1-3. Retrieved April 4, 2013, from http://hermetic.com/crowley/equinox/equinox-Ii.pdf

Crowley, Aleister. 1912a. Editorial. Equinox 1 (8): xxiii-xxvi. Retrieved April 4, 2013, from http://hermetic.com/crowley/equinox/equinox-Iviii.pdf

Crowley, Aleister. 1912b. A brief abstract of the symbolic representation of the universe derived by Doctor John Dee through the skrying of Sir Edward Kelly. Equinox 1 (7): 229-243. Retrieved April 4, 2013, from http://hermetic.com/crowley/equinox/equinox-Ivii.pdf

Decker, Ronald, \& Dummett, Michael. 2002. A History of the Occult Tarot, 1870-1970. London: Duckworth.

Decker, R., Depaulis, T., \& Dummett, M. 1996. A Wicked Pack of Cards: The Origins of the Occult Tarot. New York: St Martin's Press. 
Devereux, G., ed. 1953. Psychoanalysis and the Occult. New York: International Universities Press.

Dobb, Maurice 1972. Studies in the Development of Capitalism. New York: Taylor \& Francis.

Doering-Manteuffel, Sabine. 2011. Survival of occult practices and ideas in modern common sense. Public Understanding of Science 20 (3): 292-302.

Dummett, Michael. 1980. The Game of Tarot. London: Duckworth.

Dummett, Michael. 2007. Six XV-century tarot cards. Who painted them? Artibus et Historiae. 28 (56): 15-26.

Durkheim, Emile. 1915. The Elementary Forms of Religious Life: A Study in Religious Sociology. London: Allen \& Unwin. Retrieved April 4, 2013, from http://archive.org/details/elementaryformso00durkrich

Elias, Norbert. 1994. The Civilizing Process: The History of Manners and State Formation and Civilization. Oxford: Blackwell.

Farley, H. 2009. A Cultural History of Tarot. London: I.B. Tauris

Fairclough, Norman 2001. Language and Power. Toronto: Pearson Education ESL.

Collins, H. M., \& Pinch, T. J. 1982. Frames of Meaning: The Social Construction of Extraordinary Science. London: Routledge \& Kegan Paul.

Forman, Robert. 1999. Mysticism, Mind, Consciousness. Albany: State University of New York Press.

Foucault, Michael. 1975. Discipline and Punish: The Birth of the Prison. New York: Vintage.

Freud, Sigmund. 2012. The Future of an Illusion. Buffalo: Broadview Press.

Gad, I. 1994. Tarot and Individuation: Correspondences with Cabala and Alchemy. York Beach, ME: Nicholas-Hays.

Gorski, Philip S. 1993. The Protestant ethic revisited: Disciplinary revolution and state formation in Holland and Prussia. American Journal of Sociology 99 (2): 265-316.

Gyimesi, Julia. 2012. Sandor Ferenczi and the Problem of Telepathy. History of the Human Sciences 25 (2): 131-148.

Hammer, Olav. 2004. Claiming Knowledge: Strategies of Epistemology from Theosophy to the New Age. Leiden: Brill.

Hanegraaff, Wouter, J. 2005. Forbidden knowledge: Anti-esoteric polemics and academic research. Aries 5 (2): 225-54.

Head, Al. 2012. The queer fool. Sexualities 15 (3): 3-10.

Hess, D. J. 2007. Spirits and Scientists: Ideology, Spiritism, and Brazilian Culture. Pennsylvania: Penn State University Press. 
Horn, Eva. 2011. Logics of political secrecy. Theory, Culture \& Society 28 (7-8): 103-122.

Ivtzan, Itai. 2007. Tarot cards: A literature review and evaluation of psychic versus psychological explanations. Journal of Parapsychology 71 (Spring): 139-149.

Jacob, Margaret C. 1981. The Radical Enlightenment. Pantheists, Freemasons and Republicans. London: Allen and Unwin.

Jayanti, Amber. 1988. Living the Tarot: Applying an Ancient Oracle to the Challenges of Modern Life. London: Wordsworth.

Jewkes, Yvonne. 2005. Men behind bars: "Doing" masculinity as an adaptation to imprisonment. Men and Masculinities 8 (1): 44-63.

Jorgensen, Danny L. 1982. The esoteric community: an ethnographic investigation of the cultic milieu. Journal of Contemporary Ethnography 10: 383-407.

Jorgensen, Danny L., \& Jorgensen, Lin. 1982. Social meanings of the occult. The Sociological Quarterly 23 (3): 373-389.

Kieser, Alfred. 1998. From Freemasons to industrial patriots. Organizing and disciplining in 18th century Germany. Organization Studies 19 (1): 4771.

Kloosterman, Ingrid. 2012. Psychical research and parapsychology interpreted: Suggestions from the international historiography of psychical research and parapsychology for investigating its history in the Netherlands. History of the Human Sciences 25 (2): 2-22.

Knoop, Douglas, and Jones, G. P. 1947. The Genesis of Freemasonry. An Account of the Rise and Development of Freemasonry in its Operative, Accepted and Early Speculative Phases. Manchester: Manchester University Press.

Koselleck, R. 1988. Critique and Crisis: Enlightenment and the Pathogenesis of Modern Society. Oxford: Berg.

Lachman, Gary. 2011. Secret Societies. Retrieved April 3, 2013, from http:// garylachman.co.uk/2011/10/18/secret-societies/

Levi, Eliphas. 2002. The Key of the Mysteries. New York: Red Wheel/Weiser.

Laqueur, Walter. 1996. Fin-de-siècle: Once more with feeling. Journal of Contemporary History 31 (1): 5-47.

Lundskow, George. 2008. The Sociology of Religion: A Substantive and Transdisciplinary Approach. London: Pine Forge Press.

Maitre, J. \& Becker, Chris. 1966. The consumption of astrology in contemporary society. Diogenes 14 (53): 82-98.

Mannheim, Ernst. 1979. Aufklärung und öffentliche Meinung. Studien zur Soziologie der Öffentlichkeit in 18. Jarhundert. Hrsg. v. Norbert Schindler. Stuttgart-Bad Cannstadt: Frommann-Holzboog. 
Marx, Karl. 1848. The Communist Manifesto. Retrieved April 4, 2013, from. http://www.marxists.org/archive/marx/works/1848/communist-manifesto/

Maslow, Abraham. 1943. A theory of human motivation. Psychological Review 50: 270-296. Retrieved April 4, 2013 from http://psychclassics.yorku.ca/ Maslow/motivation.htm

Mathers, MacGregor. 2008. The tarot. Its occult significance, use in fortunetelling \& method of play. Retrieved April 4, 2013 from the website of the Esoteric Order of the Golden Dawn: http://www.esotericgoldendawn. com/mysteries tarot tarotmathers.htm

McLaughlin, T. 1996. Street Smarts and Critical Theory. Madison: University of Wisconsin Press.

Miller, David, \& Dinan, William. 2007. A Century of Spin: How Public Relations Became the Cutting Edge of Corporate Power. New York: Pluto Press.

Nasierowski, Tadeusz, \& Britman, Jonathan. 2012. Freemasonry and psychiatry in Poland. History of Psychiatry 23 (3): 329-341.

Nichols, Sallie. 1974. The wisdom of the Fool. Psychological Perspective: A Quarterly Journal of Jungian Thought 5 (2): 97-116.

Nichols, Sallie. 1980. Jung and Tarot: An Archetypal Journey. San Francisco: Weiser Books.

Nicholson, Christina 2003. How to believe six impossible things before breakfast: Irigaray, Alicer, and Neo-pagan negotiation of the otherworld. Feminist Theology 11: 362-74.

Noddings, N. and P. Shore. 1984. Awakening the Inner Eye: Intuition in Education. New York: Teachers College, Columbia University.

Ouspensky, P. D. 1976. The Symbolism of the Tarot: Philosophy of Occultism in Pictures and Numbers. Mineola, NY: Dover Publications.

Owen, A. 2004. The Darkened Room: Women, Power and Spiritualism in Late Victorian England. Chicago: University of Chicago Press.

Place, Robert M. 2005. The Tarot: History, Symbolism, and Divination. New York: Jeremy P. Tarcher.

Pollack, Rachel. 1980. Seventy-eight Degrees of Wisdom: A Book of Tarot. Wellingborough, Northhampton: Aquarian Press.

Pratesi, Franco. 1989. Tarot in bologna: documents from the university library. The Playing-card 17 (4): 136-146. Retrieved April 4, 2013, from http:// trionfi.com/pratesi-cartomancer

Redden, Guy. 2011. Religion, cultural studies and New Age sacralization of everyday life. European Journal of Cultural Studies 14 (6): 649-663.

Remy, J. 1990. Patriarchy and fratriarchy as forms of andocracy. In J. Hearn \& D. Morgan (Eds.), Men, masculinity and social theory. London: Allen \& Unwin. 
Rigoglioso, Marguerite. 2005. Interview with Starhawk. Feminist Theology 13: 173-183.

Robbins, T., \& Anthony, D. The sociology of contemporary religious movements. Annual Review of Sociology 5: 75-89.

Roberts, John M. 1972. The Mythology of the Secret Societies. New York: Scribner.

Rosengarten, Arthur. 2000. Tarot and psychology: Spectrums of possibility. St Paul, MN: Paragon House.

Rossi, E. L. 1986. The Psychobiology of Mind-body Healing. New York: Norton.

Rudin, Marcia R. 1990. Cults and satanism: Threats to teens. NASSP Bulletin 74 (526): 46-52.

Santarcangeli, Paolo. 1979. The jester and the madman, heralds of liberty and truth. Diogenes 27 (106): 28-40.

Schindler, Norbert. 1982. Freimaurerkulture in 18. Jahrhundert. Zur sozialen funktion des geheimnisses in der entstehenden bürgerlichen gesellschaft. In R. M. Berdahl et al. (Eds.). Klassen und culture: Sozialanthropologische perspektiven in der geschichtsschreibung. Frankfurt an Main: Syndicat.

Sech, Alexandre, de Freitas, Saulo, \& Moreira-Almeida, Alexander. (2013). William James and psychical research: Towards a radical science of mind. History of Psychiatry 24 (1): 62-78

Semetsky, Inna. 2000. Symbolism of the Tower as abjection. Parallax 6 (2): 110122.

Semetsky, Inna. 2009. Transforming ourselves/transforming curriculum: Spiritual education and tarot symbolism. International Journal of Children's Spirituality 14 (2): 105-120

Semetsky, Inna. 2010a. Interpreting the signs of the times: Beyond Jung. Social Semiotics 20 (2): 103-120.

Semetsky, Inna. 2010b. When Cathy was a little girl: The healing praxis of tarot images. International Journal of Children's Spirituality 15 (1): 59-72.

Semetsky, Inna. 2011a. Tarot images and spiritual education: The three I's model. International Journal of Children's Spirituality 16 (3): 249-260.

Semetsky, Inna. 2011b. Re-symbolization of the self: Human development and tarot hermeneutic. Rotterdam: Sense Publishers.

Simmel, Georg. 2006. The sociology of secret societies. American Journal of Sociology 11: 441-498.

Sharp, M. (2006). The Book of Light: The Nature of God, the Structure of Consciousness, and the Universe Within You (Vol. One - Air). St. Albert, Alberta: Lightning Path Press. 
Sharp, M. (2009). The Book of the Triumph of Spirit: Halo/Sharp New Energy Archetypes. St. Albert: Lightning Path Press.

Sharp, M. (2013). The Book of Triumph of Spirit: Healing and Activating with the Halo/Sharp System. St. Albert: Lightning Path Press.

Sharp, M. (unpublished). The Book of the Triumph of Spirit: Master Key. St Albert, Alberta: Lightning Path Press.

Sommer, Andreas. 2012. Psychical research and the origins of American psychology: Hugo Munsterberg, William James and Eusapia Palladino. History of the Human Sciences 25 (2): 23-44.

Sosteric, M. (under review) Doing the Sociology of Religion.

Sosteric, Mike. 2013. Sociology 231: Sociology of religion. Athabasca, AB: Athabasca University.

Sosteric, Mike. (in progress) The Ideology of Tarot.

Sosteric, Mike. (in progress(a)). Inscribing a Revolutionary Tarot: The "New Energy" Halo/Sharp.

Spain, D. (1992). Gendered spaces. Chapel Hill: University of North Carolina Press.

Spiegelman, Marvin J. 1998. The scientific and mythological basis of divination. Psychological Perspectives: A Quarterly Journal of Jungian Thought 37 (1): 92-107.

Staudenmaier, Peter. 2009. Occultism, race and politics in German-speaking Europe, 1880 -1940: A Survey of Historical Literature. European History Quarterly 39: 47-70.

Steiner, Rudolf. 1957. Occult history. London: Rudolf Steiner Press.

Stone, Alison. 2006. Adorno and the disenchantment of nature. Philosophy \& Social Criticism 32 (2): 231-253.

Swimme, B. (1988). The Cosmic Creation Story. In D. R. Griffin (Ed.), The Reenchantment of Science (pp. 47-56). New York: State University of New York.

Truzzi, M. 1974a. Definitions and dimensions of the occult: Towards a sociological perspective. In E. A. Tiryakian (Ed.), On the margin of the visible: Sociology, the esoteric and the occult (pp. 243-257). New York: John Wiley.

Truzzi, M. 1974b. Towards a sociology of the occult: Notes on modern witchcraft. In I. I. Zaretsky and M. P. Leone (Eds.), Religious movements in contemporary America (pp. 628-645). Princeton, NJ: Princeton University Press.

Versluis, Arthur. 2007. Magic and Mysticism: An Introduction to Western Esotericism. New York: Rowan and Littlefield. 
van Dülmen, Richard. 1986. Die gesellschaft der aufklärer. Zur bürgerlichen emanzipation und aufklärerischen kultur in Deutschland. Frankfurt am Main: Fischer.

Von Eckartshausen, Councillor. 1909. An Account of A $\therefore$ A $\therefore$ first written in the language of his period. Equinox 1(1). Retrieved April 4, 2013, from http://hermetic.com/crowley/equinox/i/i/eqi01003.html Weatherly, Joan. 1986. Yeats, the tarot, and the Fool. College Literature 13(1): 112-121.

Weber, Max. 1987. The Sociology of Religion (4th ed.). Boston: Beacon.

Weber, Max. 2003. The Protestant Ethic and the Spirit of Capitalism. London: Dover.

Wilber, Ken. 1996 The Atman Project: A Transpersonal View of Human Development. Wheaton, IL: Quest Books.

Wilber, Ken. 2000. Integral Psychology. Boston: Shambhala.

Wilber, Ken. 2001. Quantum Questions: Mystical Writings of the World's Great Physicists. Boston: Shambhala.

Wood, Juliette. 1998. The Celtic tarot and the secret tradition: A study in modern legend making. Folklore 109: 15-24.

Woofitt, Robin. 2000. Some properties of the interactional organization of displays of paranormal cognition in psychic-sitter interaction. Sociology 34 (3): 457-479.

Yates, Frances A. 1975. The Rosicrucian Enlightenment. London: Paladin.

Zaretsky, I. I. and Leone, M. P. (eds.). 1974. Religious Movements in Contemporary America. Princeton, NJ: Princeton University Press.

Mike Sosteric is Associate Professor of Sociology at Athabasca University. He teaches the Sociology of Religion, Sociology of Technology, and Science and Mysticism courses. He is the coordinator and author of several successful sociology courses. He is currently working to establish a Sociology of the Occult and a Sociology of Tarot and has created his own critically oriented tarot deck, the Halo/Sharp deck. 
392 C Canadian Journal of Sociology/Cahiers Canadiens de sociologie 39(3) 2014 